\title{
PENDAPAT PIMPINAN-PIMPINAN GEREJA DI BEKASI TENTANG IZIN PENDIRIAN RUMAH IBADAH DALAM PERATURAN BERSAMA MENTERI TAHUN 2006
}

\author{
Binsar A. Hutabarat \\ Reformed Center for Religion and Society
}

\begin{abstract}
The article, entitled "Opinion The church Leaders in Bekasi on the Permit Construction of Houses of Worship in the Joint Regulation of the Minister of the Year 2006, will be explained about the implementation of policies permit the establishment of houses of worship in Joint Regulation of the Minister (PBM) in 2006 in Bekasi, as well as the implications for church in that place, through the opinion of the church leaders in Bekasi. First, authors will describe the Guarantee Rights of Religion, Belief, Worship and Establish Home Worship based on Pancasila and the Indonesian Constitution, the Universal Declaration of Human Rights, The Covenant, and documents declarations of the United Nations (UN), and also explained about permit the establishment of houses of worship of Letters Joint Decree (SKB) until the PBM. After that, will be presented regarding the results of the opinion of the church leaders in Bekasi on the implementation of the policy permits a house of worship in Bekasi. Opinion leaders in Bekasi Church will be grouped in four categories, namely: A) The church which has a license, and not problematic. B) The church is having problems obtaining a license, a problem with the public, but finish. C)
\end{abstract}


The church that does not have a license but has no problem with the community. D) The church that does not have permissions and have problem with the community, and did not finish. The findings obtained are church leaders in the four categories above found PBM on authorizing the establishment of houses of worship contrary to Pancasila and the Indonesian Constitution and the values of human rights are universal, and implementation of government policies that adversely affect the lives of religious believers in Bekasi, both in the internal relations of religion, as well as in interreligious relations.

KEYWORDS: permit the establishment of houses of worship, Joint Ministerial Decree, Pancasila, the Indonesian constitution, human rights.

ABSTRAK: Artikel yang berjudul Pendapat Pimpinanpimpinan Gereja di Bekasi tentang Izin Pendirian Rumah Ibadah dalam Peraturan Bersama Menteri Tahun 2006 ini akan memaparkan mengenai implementasi kebijakan pengurusan izin pendirian rumah ibadah dalam Peraturan Bersama Menteri (PBM) Tahun 2006 di Bekasi, serta dampaknya bagi gerejagereja di Bekasi menurut pendapat pimpinan-pimpinan gereja di Bekasi. Pertama-tama penulis akan memaparkan mengenai Jaminan Hak Beragama, Berkeyakinan, Beribadah dan Mendirikan Rumah Ibadah berdasarkan Pancasila dan UUD 45, Deklarasi Universal HAM, Kovenan dan dokumen deklarasi Perserikatan Bangsa-Bangsa (PBB), kemudian juga memaparkan mengenai izin pendirian rumah ibadah dari SKB 
sampai dengan PBM. Setelah itu akan dipaparkan mengenai pendapat pimpinan-pimpinan gereja di Bekasi tentang implementasi kebijakan pengurusan izin rumah ibadah di Bekasi. Pendapat pemimpin-pemimpin gereja di Bekasi ini akan dikelompokkan pada empat kategori yakni: A) Gereja yang memiliki izin dan tidak bermasalah. B) Gereja yang mengalami masalah pengurusan izin, bermasalah dengan masyarakat, tetapi selesai. C) Gereja yang tidak memiliki izin namun tidak bermasalah dengan masyarakat. D) Gereja yang tidak memiliki izin, bermasalah dengan masyarakat, dan tidak selesai. Temuan yang didapatkan adalah pemimpin-pemimpin gereja dalam empat kategori di atas berpendapat bahwa PBM tentang Izin Pendirian Rumah Ibadah bertentangan dengan Pancasila dan UUD 45 serta nilai-nilai hak-hak asasi yang universal, dan implementasi kebijakan pemerintah tersebut berdampak buruk dalam kehidupan antarumat beragama di Bekasi, baik dalam hubungan internal agama, maupun dalam hubungan antaragama.

KATA KUNCI: izin pendirian rumah ibadah, Peraturan Bersama Menteri, Pancasila, UUD 45, Hak-hak Asasi Manusia

\section{PENDAHULUAN}

Kebebasan beragama dan berkeyakinan secara langsung juga mensyaratkan adanya hak kebebasan mendirikan rumah ibadah sesuai dengan agama dan kepercayaan masing-masing. Hak kebebasan beragama dan berkeyakinan ini tergolong ke dalam kategori hak yang harus dilindungi dan tidak dapat 
dibatasi atau bahkan dilanggar dalam kondisi apapun (NonDerogable Right), dan hak ini secara langsung mensyaratkan adanya kebebasan menjalankan ibadah, atau beribadah dan mendirikan rumah ibadah. Hak menjalankan ibadah dan mendirikan rumah ibadah ini tergolong kategori hak yang dapat dibatasi (Derogable Right). Pembatasan hak ini hanya bisa diberlakukan terkait dengan kondisi darurat di sebuah negara. ${ }^{1}$

Arti penting sebuah rumah ibadah untuk menjalankan ibadah secara bersama-sama itulah yang membuat pemerintah Indonesia pada awalnya tidak mewajibkan pengurusan izin pendirian rumah ibadah, apalagi pada awalnya daerah-daerah di Indonesia umumnya bersifat homogen. Namun, seiring dengan berjalannya waktu, dan perpindahan penduduk yang makin tinggi, maka daerah-daerah di Indonesia menjadi lebih heterogen, dan hadirlah persoalan terkait dengan pendirian rumah ibadah.

Untuk mengatasi konflik tentang pendirian rumah ibadah, pemerintah Indonesia mengeluarkan peraturan tentang

${ }^{1}$ Pasal 4 Kovenan Internasional Hak-hak sipil mengatakan: Dalam keadaan darurat yang mengancam kehidupan bangsa dan keberadaannya, yang telah diumumkan secara resmi, negara-negara kovenan ini dapat mengambil langkah-langkah yang mengurangi kewajiban-kewajiban mereka berdasarkan kovenan ini, sejauh memang sangat diperlukan dalam situasi darurat tersebut, sepanjang langkah-langkah tersebut tidak bertentangan dengan kewajiban-kewajiban lainnya berdasarkan hukum internasional dan tidak mengandung diskriminasi semata-mata berdasarkan atas ras, warna kulit, jenis kelamin, bahasa, agama atau asal usul sosial. Papang Hidayat dan Puri Kencana Putri, Panduan Pemolisian dan Hak Berkeyakinan, Beragama, dan Beribadah (Jakarta: Kontras, 2012), 31. 
pendirian rumah ibadah. Peraturan tentang pendirian rumah ibadah ini pertama kali dikeluarkan pada tahun 1969 dalam bentuk Surat Keputusan Bersama (SKB) Menteri Agama dan Menteri Dalam Negeri Nomor 01/BER/MDN/1969 tentang Pelaksanaan Tugas Aparatur Pemerintahan dalam Menjamin Ketertiban dan Kelancaran Pelaksanaan Pengembangan dan Ibadat oleh Pemeluk-pemeluknya.

Implementasi SKB tersebut ternyata kemudian terindikasikan dijadikan instrumen bagi penutupan gereja di berbagai tempat. Dengan alasan itu kemudian pemerintah merevisi SKB tersebut menjadi Peraturan Bersama Menteri (PBM) No 9/2006 dan 8/2006, dan di dalamnya juga mengatur pendirian rumah ibadah. PBM memang memiliki perbedaan dengan SKB, namun keduanya memiliki persamaan, yakni mensyaratkan keharusan pengurusan izin rumah ibadah.

Pada awal ditetapkannya peraturan tersebut, April 2006, Gomar Gultom, waktu itu duduk sebagai Sekretaris Eksekutif Bidang Diakonia PGI, pernah mengatakan, Kendati PBM tidak sesuai dengan prinsip-prinsip HAM, terutama kebebasan beribadah, PBM diharapkan bisa membantu masyarakat Indonesia yang sangat majemuk untuk menjalankan ibadah dengan baik. ${ }^{2}$ Mengutip apa yang diungkapkan Andreas A. Yewangoe, yang pada saat diterbitkannya PBM duduk sebagai Ketua Umum PGI, Gomar Gultom selanjutnya menegaskan, "Kalau ternyata PBM ini lebih melancarkan pembangunan gedung-gedung ibadah sebagai wujud kerukunan otentik di

2 Gomar Gultom (ed.), Dari SKB ke PBM (Jakarta: PGI, 2006), 10. 
antara warga, maka ia telah menjadi berkat bagi negeri ini. Kalau sebaliknya, maka PBM ini mesti ditinjau kembali, bahkan dicabut." 3

Tulisan ini akan meneliti apakah PBM telah menjadi solusi bagi penyelesaian konflik terkait perizinan pendirian rumah ibadah di Indonesia? Tulisan ini secara khusus juga meneliti dampak PBM terhadap hubungan internal agama dan hubungan antaragama yang berbeda di Bekasi.

\section{JAMINAN HAK BERAGAMA, BERKEYAKINAN, BERIBADAH DAN MENDIRIKAN RUMAH IBADAH}

Hak beragama, berkeyakinan dan beribadah secara tegas dinyatakan dalam Pancasila, khususnya sila pertama. Mengenai pengertian dari sila Ketuhanan yang Maha Esa, Soekarno pencetus istilah Pancasila menjelaskan seperti berikut:

Prinsip yang kelima hendaknya menyusun Indonesia merdeka dengan bertakwa kepada Tuhan yang Maha Esa. Prinsip ketuhanan, bukan saja karena bangsa Indonesia bertuhan, tetapi masing-masing orang Indonesia hendaknya bertuhan, sesuai keyakinan masing-masing. Orang Kristen menyembah Tuhan menurut petunjuk Isa Almasih, Islam bertuhan menurut petunjuk Nabi Muhammad SAW. Orang Buddha menjalankan ibadahnya menurut petunjuk kitab-kitab mereka, dan seterusnya. Tetapi marilah kita semuanya bertuhan. Hendaknya negara Indonesia ialah negara yang tiap-tiap orangnya dapat

${ }^{3}$ Ibid. 
menyembah tuhannya dengan cara leluasa. Segenap rakyat Indonesia hendaknya bertuhan secara kebudayaan, yakni dengan tiadanya "egoisme agama" dan hendaknya negara Indonesia satu negara yang bertuhan. ${ }^{4}$

Dalam pidato tersebut, Soekarno menyatakan supaya semua warga negara memeluk agama yang sesuai dengan keyakinannya, dan negara menjamin kebebasan setiap orang untuk menjalankan ibadah agamanya masing-masing. Jaminan kebebasan beribadah ini juga dinyatakan dalam pasal 29 UUD 1945 ayat 2, di mana dijelaskan, negara menjamin kemerdekaan tiap-tiap penduduk untuk memeluk agamanya masing-masing dan untuk beribadah menurut agamanya dan kepercayaannya itu.

Senada dengan Soekarno, TB Simatupang mengatakan secara tegas bahwa :

Sila pertama bukanlah "kepercayaan kepada Allah" tetapi lebih berarti kepercayaan kepada "ide ketuhanan", oleh karena kata yang dipakai di sini bukanlah "Allah" tetapi istilah yang lebih netral, "Ketuhanan". Kepada istilah tersebut ditambahkan pula keesaan dan kemahaan. Demikianlah sila yang pertama tidak berbicara tentang Allah, tetapi tentang ke-allahan. Ia berbicara tentang keilahian. Juga orang-orang yang tidak mempercayai Allah yang bersifat pribadi, misalnya beberapa kalangan dalam

${ }^{4}$ Ruslan Abdulgani, Pancasila Perjalanan Sebuah Ideologi (Jakarta: Grasindo, 1998), 15. 
agama Budha, dapat menerima sila tersebut. Ia berbicara tentang kepercayaan kepada sesuatu yang maha transenden. Sesuatu yang maha esa, mungkin ini terdengar sebagai suatu konsep yang amat samar-samar, tetapi ia berhasil merangkul semuanya. ${ }^{5}$

Uraian Soekarno dan Simatupang mengenai Pancasila sangat jelas. Bahwa sila Ketuhanan yang Maha Esa tidak boleh diartikan secara teologis. Yang dimaksud dengan penafsiran secara teologis misalnya adalah menafsirkan kata Ketuhanan yang Maha Esa sebagai tauhid dalam agama Islam, ${ }^{6}$ karena ia adalah gambaran pengakuan bahwa semua agama mempunyai tempat di bumi Indonesia. Sila tersebut juga merupakan suatu pengakuan bahwa negara Indonesia adalah negara yang memiliki banyak agama, dan memberi tempat yang sama terhadap semua agama. Karena itu semua agama, termasuk aliran kepercayaan memiliki hak untuk beribadah baik secara individu maupun secara berkelompok.

Berdasarkan Pancasila dan UUD 1945 jelaslah bahwa UU nomor 23 Tahun 2006 tentang Administrasi Kependudukan, khusus dalam pasal 8 ayat (4) yang menerangkan bahwa Pemerintah Indonesia hanya mengakui enam agama resmi yakni Islam, Katolik, Kristen, Hindu, Buddha, Kong $\mathrm{Hu} \mathrm{Cu}$ harus dicabut, karena ayat tersebut jelas-jelas

${ }_{5}^{5}$ T.B. Simatupang, Iman Kristen dan Pancasila (Jakarta: BPK Gunung Mulia, 1998), 4.

${ }^{6}$ Endang Saefuddin Anshari, Piagam Jakarta 22 Juni 1945 (Jakarta: Gema Insan Press, 1997), xxiii. 
mendiskriminasikan aliran kebatinan yang jumlah ratusan di Indonesia, demikian juga agama-agama lokal yang berkembang ditengah masyarakat Indonesia. ${ }^{7}$

Terkait dengan aliran kebatinan atau kepercayaan Mahkamah Konstitusi memberikan pertimbangan demikian:

Menimbang... Demikian juga terhadap kepercayaan terhadap Tuhan Yang Maha Esa yang sejak awal lahir dan bertumbuh di bumi Indonesia tetap diakui dan dihormati. Adapun mengenai bukti surat edaran dari Departemen Dalam negeri yang diajukan oleh para pemohon...Menimbang bahwa terhadap kepentingan masyarakat penganut kepercayaan yang sudah lama hidup di Indonesia, Mahkamah berpendapat, masyarakat penganut kepercayaan adalah masyarakat yang memiliki hak dan kewajiban yang sama dalam meyakini kepercayaannya sesuai dengan jaminan yang diberikan dalam Pasal 28E ayat (2)UUD 1945. Praktik diskriminasi yang dialami oleh masyarakat penganut kepercayaan adalah bentuk dari kesalahan penerapan norma dalam hukum administrasi dan bukan merupakan permasalahan pertentangan norma UU Pencegahan Penodaan Agama terhadap UUD 1945." 8

Jaminan kebebasan beragama dan beribadah secara jelas dituangkan dalam Deklarasi Universal HAM 1948 pasal 18: Setiap orang berhak atas kebebasan pikiran, hati nurani, dan

7 Panduan Pemolisian (Jakarta: Kontras, 2012), 36.

8 Ibid., 11-12. 
agama. Dengan kebebasan untuk menyatakan agama atau kepercayaan dengan cara mengajarkannya, melakukannya, beribadat dan menaatinya, baik sendiri maupun bersama-sama dengan orang lain, di muka umum maupun sendiri. Kebebasan beragama dan berkeyakinan ini tergolong ke dalam kategori hak yang harus dilindungi dan tidak dapat dibatasi atau bahkan dilanggar dalam kondisi apapun (Non-Derogable Right). Dan hak ini secara langsung mensyaratkan adanya kebebasan menjalankan ibadah, atau beribadah dan mendirikan rumah ibadah. Dan hak menjalankan ibadah dan mendirikan rumah ibadah ini tergolong kategori hak yang dapat dibatasi (Derogable Right). Pembatasan tersebut menurut DUHAM Pasal 18 ayat (2) berbunyi seperti berikut:

Kebebasan menjalankan dan menentukan agama atau kepercayaan seseorang hanya dapat dibatasi oleh ketentuan berdasarkan hukum, dan yang diperlukan untuk melindungi keamanan, ketertiban, kesehatan, atau moral masyarakat, atau hak-hak kebebasan mendasar orang lain. Perserikatan BangsaBangsa secara khusus menjamin adanya perlindungan atas rumah-rumah ibadah yang digunakan oleh warga. Hak untuk membangun rumah ibadah merupakan perwujudan dari kebebasan beragama atau berkeyakinan, sebagaimana hak untuk menggunakan dan memasang simbol agama/keyakinan, dan menjalankan hari libur keagamaan/keyakinan. ${ }^{9}$

${ }^{9}$ Ibid., 19. 
Selain dokumen DUHAM 1948, Kovenan Internasional Hak-Hak Sipil dan Politik, ada dua dokumen lain yang dideklarasikan PBB, dan dokumen-dokumen tersebut menyediakan standar-standar internasional yang diakui secara luas, serta dapat digunakan sebagai rujukan untuk menyelesaikan masalah-masalah HAM. Pertama adalah dokumen Deklarasi untuk Mengeliminasi Segala Bentuk Praktik Intoleransi dan Diskriminasi Berdasarkan Agama dan Kepercayaan (Declaration on Elimination of All Forms Intolerance and Discrimination Based on Religion or Belief). Pasal 2 Deklarasi ini mewajibkan negara untuk mengambil tindakan efektif dalam mencegah atau menghapus praktik diskriminasi berbasis agama dan keyakinan. Bahkan negara juga memiliki kewajiban untuk membatalkan setiap produk perundang-undangan yang berisi pesan dikriminasi. Kedua, dokumen Deklarasi untuk Melindungi Hak-hak Individu Minoritas untuk Bidang Nasionalitas/Etnis, Agama, dan Bahasa (Declaration on the Rights of Persons Belonging to National or Ethnic, Religious and Linguistic Minorities). Pasal 4 ayat (2) Deklarasi tersebut menyatakan negara juga berkewajiban untuk memberikan perlindungan bagi individu-individu minoritas agar mereka bisa menjalankan ritual agamanya dengan bebas. Negara juga berkewajiban untuk mengambil tindakan efektif untuk menciptakan iklim kondusif agar individu-individu minoritas dapat menjalankan ibadahnya dengan baik. ${ }^{10}$

10 Ibid., 20. 


\section{IZIN MENDIRIKAN RUMAH IBADAH DALAM PBM}

Perlunya izin khusus pendirian rumah ibadah di Indonesia berawal dengan diterbitkannya Surat Keputusan (SK) Menteri Agama dan Menteri Dalam Negeri Nomor: 01/BER/MDN-MAG/1969 tentang Pelaksanaan Tugas Aparatur Pemerintahan dalam Menjamin Ketertiban dan Kelancaran Pelaksanaan Pengembangan dan Ibadat Agama oleh Pemelukpemeluknya. Dalam pasal 4 ayat 1 dijelaskan bahwa pendirian rumah ibadah perlu mendapat izin dari kepala daerah atau pejabat pemerintah di bawahnya yang dikuasakan untuk itu. SK-SK bersama mengenai peraturan untuk mendirikan rumah ibadah itu hanya mengatur pendirian rumah ibadah untuk orang Kristen. ${ }^{11}$ Karena memang latar belakang dikeluarkannya SK tersebut karena ada gejala-gejala bahwa di beberapa daerah jumlah umat Kristen bertambah dengan pesat, dan di beberapa tempat terjadi perusakan terhadap gedung gereja. ${ }^{12}$

Hadirnya SKB Dua Menteri yang mengatur perizinan rumah ibadah pada awal ditetapkannya mendapat penolakan dari gereja-gereja di Indonesia. PGI (waktu itu masih bernama DGI) membuat sebuah memorandum, tertanggal 10 Oktober 1969, yang meminta pemerintah untuk meninjau kembali SKB itu. Memorandum yang ditandatangani oleh Ds. W.J. Rumambi (Sekretaris Departemen Gereja dan Masyarakat DGI) dan Pastor F.X. Danuwinata, SJ. (MAWI) tidak ditanggapi, dan

11 T.B. Simatupang, Membuktikan Ketidakbenaran Suatu Mitos (Jakarta: BPK Gunung Mulia, 1987), 240.

12 Ibid. 
diberlakukan selama 37 tahun meski secara jelas terbukti telah mendiskriminasikan agama Kristen khususnya dalam pendirian rumah ibadah. ${ }^{13}$

Pada pasal 4 SKB No. 1/1969 aturan pendirian rumah ibadah sebagai berikut: ${ }^{14}$

1. Setiap pendirian rumah ibadat perlu mendapatkan izin dari kepala daerah atau pejabat pemerintahan di bawahnya yang dikuasakan untuk itu.

2. Kepala Daerah atau pejabat yang dimaksud dalam ayat (1) pasal ini memberikan izin yang dimaksud setelah mempertimbangkan:

a. Pendapat Kepala Perwakilan Departemen Agama setempat.

b. Planologi

c. Kondisi dan keadaan setempat

3. Apabila dianggap perlu, kepala daerah atau pejabat yang ditunjuknya itu dapat meminta pendapat dari organisasi-organisasi keagamaan dan ulama/rohaniawan setempat.

Implementasi SKB dua menteri tentang perizinan rumah ibadah ternyata tidak produktif, dan kemudian dengan alasan yang sama dengan penerbitan SKB, dilakukanlah revisi terhadap peraturan tersebut. Pada revisi peraturan tersebut pendirian rumah ibadah dinyatakan lebih detail seperti dalam Bab IV Pasal 13-17. Pasal 14 menyebutkan: (1) Pendirian rumah

${ }^{13}$ Gultom (ed.), Dari SKB ke PBM, 10.

14 Ibid., 12. 
ibadat harus memenuhi persyaratan administratif dan persyaratan teknis bangunan gedung. (2) Selain memenuhi persyaratan sebagaimana dimaksud pada ayat (1) pendirian rumah ibadah harus memenuhi persyaratan khusus meliputi: A) daftar nama dan kartu tanda penduduk (KTP) pengguna rumah ibadat paling sedikit 90 (sembilan puluh) orang yang disahkan oleh pejabat setempat sesuai dengan tingkat batas wilayah sebagaimana dimaksud dalam Pasal 13 ayat (3); B) Dukungan masyarakat setempat paling sedikit 60 (enam puluh) orang yang disahkan oleh lurah/kepala desa; C) Rekomendasi tertulis kepala kantor departemen agama kabupaten/kota; dan D) Rekomendasi tertulis FKUB kabupaten/kota. Pasal 18, 19, dan 20 dalam PBM memuat ketentuan izin sementara pemanfaatan bangunan gedung bukan rumah ibadat sebagai rumah ibadat sementara, ketentuan ini tidak terdapat dalam SKB 1969.15

\section{METODOLOGI PENELITIAN}

Metodologi penelitian yang digunakan dalam kajian ini adalah kualitatif deskriptif. Tujuan penelitian deskriptif ini adalah melukiskan keadaan sesuatu atau yang sedang terjadi pada saat penelitian berlangsung. Pengumpulan data antara lain melalui kepustakaan terpilih, observasi langsung, wawancara, dan dokumentasi. Hasil wawancara tersebut kemudian ditranskripsikan, dan kemudian dilakukan reduksi

15 Ibid. 
data dengan fokus pada pendapat gereja-gereja di Bekasi terhadap izin mendirikan rumah ibadah dalam Peraturan Bersama Menteri (PBM). Penelitian dilakukan terhadap 16 gereja yang ada di Bekasi dengan melakukan observasi, wawancara langsung dengan pemimpin-pemimpin gereja tersebut, dalam hal ini pendeta dan majelis gereja. Gereja-gereja tersebut adalah: 1) HKBP Jatiasih, 2) GKP Kampung Sawah, 3) GMII Anugerah, 4) GPIB Galilea, 5) POUK Graha Prima, 6) Gemindo, 7) Gekari, 8) GPPS Talitakumi, 9) GKII Solideo, 10) GKSI Setia, 11) GBI Mawar Sharon, 12) GKI Jatibening, 13) Gekindo Jatimulya, 14) HKBP Filadelfia, 15) HKBP Ciketing, 16) GPIB Harapan Indah. Dan juga tokoh-tokoh masyarakat di Bekasi untuk konfirmasi atas data yang telah dikumpulkan. ${ }^{16}$ Gereja-gereja tersebut dikelompokkan kedalam empat kategori:
A) Gereja yang memiliki izin dan tidak bermasalah.
B) Gereja yang mengalami masalah pengurusan izin, bermasalah dengan masyarakat, tetapi selesai.
C) Gereja yang tidak memiliki izin namun tidak bermasalah dengan masyarakat.
D) Gereja yang tidak memiliki izin, bermasalah dengan masyarakat, dan tidak selesai.

Gereja dalam kategori A, adalah gereja yang memiliki kriteria seperti berikut: telah memiliki izin, tidak dipermasalahkan atau diganggu oleh masyarakat. Gereja dalam Kategori B, adalah gereja yang belum memiliki izin, dan

\section{Bekasi.}

16 Wawancara langsung dengan pemimpin-pemimpin gereja di 
keberadaannya dipersoalkan oleh masyarakat setempat karena pengurusan izin yang memakan waktu lama, dan kemudian gereja itu berhasil mendapatkan izin tesebut, dan gangguan dari masyarakat dapat diselesaikan dengan baik. Gereja dalam kategori C, tidak memiliki izin namun aman. Gereja dalam kategori D adalah gereja-gereja yang tidak berhasil mengurus izin. Gereja-gereja tersebut mendapat penolakan dari masyarakat, dan tidak dapat memenuhi persyaratan lingkungan sebagaimana dipersyaratkan oleh PBM 2006. Gereja-gereja tersebut akhirnya ditutup atau pindah ke tempat lain.

\section{SEKILAS TENTANG PERSEBARAN RUMAH IBADAH DI BEKASI}

Bekasi adalah bagian dari Provinsi Jawa Barat yang wilayahnya berbatasan langsung dengan Provinsi DKI Jakarta. Bekasi terbagi atas dua daerah tingkat dua, yakni Kota Bekasi dan Kabupaten Bekasi. Sebagai daerah yang bertetangga dengan Ibu Kota Jakarta, tentu saja Bekasi memiliki peran dan fungsi yang sangat strategis. Misalnya, Bekasi-bersama Kota Depok, Bogor, Tangerang, yang selama ini disebut-sebut sebagai "kota-kota satelit" menjadi penyangga bagi Kota Jakarta. Karena posisinya yang berbatasan langsung dengan Jakarta tersebut, Bekasi tidak dapat menghindar dari limpahan penduduk dari Jakarta dan sekitarnya. Para pendatang itu terdiri dari bermacam latar belakang agama, suku, bahasa, dan 
adat-istiadat yang berbeda-beda. ${ }^{17}$

Secara geografis Kota Bekasi posisinya berdekatan dengan Jakarta sebagai ibukota negara. Dan melihat sejarahnya, masyarakat Bekasi tidak terlalu jauh beda dari masyarakat Jakarta. Tradisi, adat-istiadat dan budayanya banyak dipengaruhi oleh nilai-nilai keagamaan, khususnya Islam. Masyarakat Kota Bekasi yang per-Juli 2009, penduduknya telah mencapai 2.457.585 jiwa, mayoritas menganut agama Islam. Jumlahnya mencapai 2.145.447 jiwa atau 87,30\%. Dan sisanya, 312.138 jiwa atau 12,70\% menganut agama lain, yakni Kristen Protestan, Katolik, Buddha, Hindu, Konghuchu, dan berbagai aliran/agama lain di luar agama-agama yang disebut di atas. Penyebaran penganut agama cukup merata pada 12 kecamatan yang ada di Kota Bekasi. Dan indikasi keberagamaan masyarakat Kota Bekasi dapat dilihat dari banyaknya rumah ibadah, baik berupa masjid (882), musholla dan langgar (1.320), gereja (207), vihara, pura, dan kelenteng (13). ${ }^{18}$

Sementara wilayah Kabupaten Bekasi terbagi ke dalam 23 kecamatan, dan setiap kecamatan meliputi 5 kelurahan dan 182 desa. Penduduk Kabupaten Bekasi (tahun 2012) berjumlah 2.786.638 jiwa. Di Kabupaten Bekasi, mesjid 1.567, musholla 614, dan langgar 2.759. Sedangkan jumlah gereja di Kabupaten Bekasi ada sebanyak 24, vihara 8 , dan pura 3. ${ }^{19}$ 2009), 5-6.

17 Badruzzaman Busyani, Rumah Ibadat di Kota Bekasi (Bekasi: FKUB,

18 Ibid., 21- 22.

${ }^{19}$ Kabupaten Bekasi dalam Angka, 2013, Agama/Religion, 56, portal.bekasi.go.id, diakses 1 Agustus 2015, pkl. 20.00 
Berdasarkan data tersebut jelaslah bahwa ketersediaan rumah ibadah umat Islam jauh lebih besar dibandingkan agama-agama lain, termasuk Kristen, apalagi rumah ibadah umat Islam dalam bentuk mushola dan langgar tidak memerlukan izin seperti masjid. Itulah sebabnya komunitas Kristen yang belum memenuhi syarat untuk mendapatkan izin mendirikan rumah ibadah pada umumnya menggunakan rumah atau ruko (rumah toko), atau fasilitas lain untuk tempat beribadah. Sebagai tempat ibadah sementara. Biasanya komunitas tersebut mengajukan permohonan untuk menggunakan gedung atau rumah tertentu sebagai tempat ibadah sementara, sampai saatnya mereka memenuhi persyaratan untuk mendapatkan izin pendirian rumah ibadah. Sulitnya mendapatkan izin mendirikan rumah ibadah mengakibatkan komunitas agama yang telah memenuhi syarat jumlah jemaat, namun belum mendapatkan persetujuan dari 60 orang dewasa warga sekitar, terpaksa terus beribadah di gedung-gedung yang dijadikan tempat ibadah sementara. Dalam laporan tahunannya (2014), Wahid Institute menempatkan Jawa Barat sebagai daerah yang paling intoleran. Dari berbagai daerah di Jawa Barat, Bekasi disebut-sebut sebagai yang paling intoleran. ${ }^{20}$

Menariknya, sekalipun Bekasi disebut paling intoleran dari seluruh daerah yang ada di Jawa Barat, Kota Bekasi juga

20 The Wahid Institute, Laporan Akhir Tahun Kebebasan Beragama/Berkeyakinan dan Intoleransi 2014, WahidInstitute.org. http://www.wahidinstitute.org/wi-id, diakses 14 April 2014, pkl. 16.15. 
memiliki daerah yang tersohor dengan toleransi beragamanya, yakni daerah Kampung Sawah. Hal ini dibuktikan dengan keberadaan tiga rumah ibadah yang berdiri megah dan letaknya berdekatan yakni Gereja Kristen Pasundan, Gereja Katolik Santo Servatius, dan sebuah masjid besar dan Pondok Pesantren Fisabillilah. Ini juga menjadi lambang kehidupan toleransi yang tinggi bagi daerah tersebut.

\section{PENDAPAT GEREJA-GEREJA DI BEKASI TERHADAP PBM}

Pendapat pimpinan-pimpinan gereja di Bekasi terkait implementasi kebijakan izin pendirian gereja menurut PBM setidaknya mencakup dua hal, yakni mengenai hubungan penetapan izin gereja terhadap pemenuhan hak membangun rumah ibadah di Bekasi, dan dampak implementasi kebijakan PBM dalam hubungan internal dan hubungan antaragama di Bekasi.

\section{PBM Bertentangan dengan Pancasila dan UUD 45}

Menurut pemimpin-pemimpin gereja di Bekasi, penetapan izin gereja, baik dalam SKB maupun PBM telah membelenggu hak masyarakat untuk mendirikan rumah ibadah. Sejak ditetapkannya, bahwa setiap pendirian rumah ibadah harus mendapatkan izin dari kepala daerah atau pejabat pemerintahan di bawahnya yang dikuasakan untuk itu. Dan kepala daerah atau pejabat memberikan izin pendirian rumah ibadah didasarkan pertimbangan: pendapat kepala perwakilan Kementerian Agama setempat, planologi, dan kondisi dan 
keadaan setempat. Menurut tokoh-tokoh gereja di Bekasi, persyaratan keharusan mendapatkan izin dari pemerintah daerah, ataupun dari masyarakat, sama saja membatasi hak mendirikan rumah ibadah. Bahkan di Bekasi, SKB dan PBM merupakan senjata untuk memberedel tempat-tempat peribadatan non-muslim. ${ }^{21}$

PBM menurut pimpinan gereja-gereja di Bekasi bukan hanya tidak mampu memfasilitasi gereja-gereja di Bekasi untuk mendapatkan izin membangun rumah ibadah, tetapi juga telah menjadi instrumen penutupan gereja, khususnya terhadap gereja-gereja yang tidak memiliki IMB. Pendataan FKUB (Forum Komunikasi Umat Beragama) terhadap rumah ibadah di Kota Bekasi yang kemudian diterbitkan dalam sebuah buku berjudul "Rumah Ibadat di Kota Bekasi", yang disunting oleh Badruzzaman Busyani, dan diterbitkan oleh FKUB Bekasi, dan di dalamnya dicantumkan nama rumah-rumah ibadah yang berizin, dan tak berizin di Kota Bekasi, khususnya gereja, menjadi tidak produktif, karena rekomendasi FKUB tidak menjamin diberikannya IMB terhadap sebuah gereja yang belum memiliki IMB, namun untuk mendapatkan IMB, sebuah gereja harus mendapatkan rekomendasi FKUB. ${ }^{22}$

\footnotetext{
${ }^{21}$ Wawancara langsung dengan pemimpin-pemimpin gereja di
} Bekasi.

${ }^{22}$ Busyani, Rumah Ibadat di Kota Bekasi (Bekasi: FKUB, 2009), 21- 22. 
Pendataan mengenai gereja-gereja yang memiliki IMB dan tidak memiliki IMB, yang kemudian dipublikasikan, mengakibatkan gereja-gereja yang tidak memiliki IMB, dan pada awalnya tidak mengalami gangguan masyarakat setempat, setelah publikasi itu justru bisa mengalami gangguan dari oknum-oknum yang tidak bertanggung jawab. Beberapa tokoh gereja mengatakan, "Di Bekasi telah hadir kelompokkelompok radikal yang kehadirannya bertujuan menutup gereja-gereja yang tidak memiliki izin." ${ }^{23}$

Pemimpin gereja di Bekasi berpendapat bahwa publikasi FKUB sangat menolong kelompok-kelompok radikal untuk mendapatkan data gereja yang tidak berizin, dan kemudian melakukan penutupan terhadap gereja tersebut, baik melalui intimidasi, pemanggilan pendeta setempat agar menutup gereja yang tidak berizin tersebut, bahkan tidak jarang penutupan gereja di Bekasi dilakukan dengan cara kekerasan apabila gereja tersebut tetap melakukan peribadatan di bangunan yang belum memiliki IMB.

Gereja-gereja dalam kategori pertama (A), yakni memiliki izin dan tidak mengalami gangguan masyarakat ternyata juga menolak PBM, menurut sumber dari gereja-gereja tersebut peraturan khusus pendirian rumah ibadah (PBM) telah menghalangi komunitas Kristen untuk memiliki rumah ibadah.

Penolakan terhadap PBM dari gereja-gereja yang telah memiliki izin dan tidak bermasalah dengan lingkungan Bekasi.

${ }^{23}$ Wawancara langsung dengan pemimpin-pemimpin gereja di 
masyarakat ternyata terkait pengalaman masa lampau gerejagereja tersebut. Ternyata gereja-gereja yang memiliki IMB dan tidak mengalami gangguan masyarakat, pada awal berdirinya juga mengalami gangguan masyarakat dengan alasan perizinan sejak diberlakukannya SKB dua menteri yang juga menetapkan keharusan mendapatkan izin pemerintah daerah dalam pendirian rumah ibadah. HKBP Jatiasih sebelum berdiri megah seperti saat ini, pernah dibakar oleh masyarakat. Namun, melalui pendekatan pihak gereja yang cukup intens terhadap masyarakat serta tokoh-tokoh masyarakat, gereja tersebut dapat didirikan kembali, dan mendapatkan izin. ${ }^{24}$ Persyaratan keharusan mendapatkan izin pemerintah yang dituangkan sejak SKB, telah mempersulit gereja, karena pertimbangan pemerintah untuk memberikan IMB gereja juga mengacu pada izin dari masyarakat setempat. Apabila masyarakat setempat ada yang tidak menginginkan hadirnya rumah ibadah agama lain, dengan alasan apapun, maka pendirian sebuah rumah ibadah akan sangat sulit didapat.

PBM tentang perizinan gereja juga menyasar Gereja Kristen Pasundan (GKP) Kampung Sawah yang telah lama berdiri dan memiliki hubungan yang harmonis dengan lingkungan. Dapat dimaklumi sebagian besar masyarakat adalah jemaat gereja tersebut. Dan bahkan lingkungan masyarakat di sana itu bersifat multi-religi. Artinya dalam sebuah keluarga bisa saja ada anggota yang berbeda keyakinan: muslim dan Kristen. Suasana yang sangat kondusif itulah yang

${ }^{24}$ Ibid. 
membuat pengurus gereja tidak berpikiran untuk mengurus surat izin. Apalagi, menurut ketentuan PBM 2006, GKP Kampung Sawah yang keberadaannya sudah sangat lama berada di daerah itu, mestinya otomatis mendapatkan izin karena GKP Jemaat Kampung Sawah berdiri sejak tanggal 16 Juni 1874.

Meskipun GKP Kampung Sawah tersebut telah berdiri sejak Indonesia belum merdeka, pemerintah setempat tetap mengharuskan pihak gereja mengurus izin sebagaimana layaknya gereja-gereja yang akan dibangun. Kasus ini sekaligus membuktikan kurangnya pemahaman pemerintah atas peraturan yang dibuatnya. Syukurlah GKP Kampung Sawah tidak memiliki masalah dengan lingkungan. Masyarakat setempat yang terdiri dari berbagai agama, sudah lama hidup dalam kebersamaan yang rukun, sehingga keberadaan gereja tersebut relatif tidak pernah mengalami hambatan. Faktor yang sangat kondusif itulah yang membuat pengurus gereja "merasa tidak perlu" mengurus izin gereja, tanpa ada maksud untuk melawan pemerintah yang berkuasa, apalagi menurut mereka PBM jelas-jelas bertentangan dengan Pancasila dan UUD 45.

Kehadiran PBM bagi gereja yang masuk dalam kategori B yakni: "mengalami masalah pengurusan izin, bermasalah dengan masyarakat, tetapi selesai", tidak semuanya merespon negatif. Gemindo, adalah salah satu gereja yang merespon positif terhadap PBM. Gereja ini harus menyusuri jalan panjang dalam pengurusan izin. Bahkan ketika pembangunan gereja telah dilakukan, dan izin belum didapat, gereja tersebut pernah 
dibakar massa. Pembangunan dapat dilakukan kembali setelah izin didapat. Dan respon positif terhadap PBM timbul karena gereja tersebut berharap PBM dapat menghindari pengalaman buruk masa lampau, yakni pembakaran gereja.

Harapan terhadap PBM itu jelas belum bisa memberikan kepastian, karena banyak gereja yang memiliki izin pun mengalami gangguan dan ada yang ditutup. Sumber dari gereja POUK Graha Prima, dan Gekari memberikan respon negatif terhadap PBM. Gereja Persekutuan Oikumene Umat Kristen (POUK) Graha Prima, pernah dibakar massa meskipun gereja tersebut berdiri di atas tanah yang disediakan pengelola Kompleks Perumahan Graha Prima dan diperuntukkan bagi rumah ibadah Kristen. Gereja tersebut harus bekerja keras melakukan pendekatan terhadap masyarakat. Setelah melalui jalan yang cukup panjang akhirnya gereja itu bisa kembali dibangun, bahkan lengkap dengan plang nama gereja. Namun demikian, surat izin belum berhasil didapat. Hal yang sama juga dilakukan Gereja Gekari, pemimpin gereja dan jemaat terus-menerus mengadakan pendekatan sosial terutama ke tokoh-tokoh agama setempat. Akhirnya upaya ini berhasil juga, di mana keberadaan gereja bisa diterima oleh masyarakat, dan kepengurusan izin pun selesai. Di sini terlihat, regulasi masyarakat yang kerap bertentangan dengan aturan PBM mendapat tempat untuk menjadi instrumen penutupan rumah ibadah. $^{25}$

${ }^{25}$ Wawancara dengan pemimpin-pemimpin gereja di Bekasi. 
Untuk kategori ketiga atau (C), yakni gereja yang tidak memiliki izin namun aman, PBM juga ditolak oleh semua gereja sampel. Antara lain, GPPS Talitakumi, gereja yang tidak memiliki izin namun diterima msyarakat setempat, dan dapat memasang plang gereja di depan bangunan gereja. Menurut pemimpin-pemimpin gereja dalam kategori $\mathrm{C}$ ini, kehadiran PBM memaksa gereja tersebut mengurus izin, padahal IMB gereja tidak mudah didapat, dan pengurusannya membutuhkan waktu yang lama. Berbeda dari GPPS Talitakumi, GKII Solideo, GKSI Setia, dan GBI Mawar Saron, ketiga gereja tersebut bukan hanya tidak bisa mengurus izin karena mereka yakin tidak akan mendapatkan izin dari masyarakat meski berdasarkan aturan PBM mereka telah memenuhi syarat jumlah jemaat. Namun karena PBM juga mensyaratkan izin dari masyarakat sekitar gereja, yang pada umumnya bukan penganut agama Kristen, maka pihak gereja tidak mengurus izin karena yakin pasti akan mengalami penolakan. Penolakan masyarakat untuk menandatangani persetujuan pendirian gereja di lingkungan mereka berada dikarenakan bahwa memberikan persetujuan pendirian gereja, sama saja dengan mengizinkan penyesatan terjadi. Kehadiran ketiga gereja tersebut telah diketahui pemerintah setempat mulai dari RT, RW, kelurahan dan kecamatan. Namun karena masyarakat dan tokoh agama sekitar lokasi gereja tersebut bukan hanya tidak menyetujui pengurusan izin gereja, untuk memasang plang nama saja, ketiga gereja tersebut tidak diizinkan. Karena itu kaharusan mendapatkan izin dari masyarakat untuk pendirian gereja, pada tempat-tempat 
tertentu di Bekasi adalah tidak mungkin. Kejadian ini secara khusus juga terjadi pada penolakan atas HKBP Filadelfia.

Untuk kategori keempat atau (D) "gereja yang tidak memiliki izin, dan bermasalah dengan masyarakat, dan tidak selesai", PBM diakui telah menjadi instrumen penutupan gereja dan menjadikan gereja sasaran kemarahan, dan kekerasan massa, tanpa pemerintah mampu melindungi gereja-gereja tersebut. Bahkan pada umumnya mereka harus meninggalkan lokasi tersebut, dan berpindah ke tempat lain. Pengalaman pahit ini dialami oleh HKBP Filadelfia, yang meskipun keberadaan mereka dimenangkan oleh Pengadilan Tata Usaha Negara (PTUN), tetap saja tempat ibadah mereka tidak dapat digunakan. Segel penutupan terhadap gereja tetap terpasang, dan mereka harus beribadah secara berpindah-pindah, termasuk di depan Istana Presiden, bersama jemaat GKI Yasmin Bogor.

HKBP Ciketing tidak hanya diganggu dan diintimidasi massa yang mengaku sebagai warga setempat. Puncaknya adalah ketika gereja tersebut diserang, dan salah seorang anggota majelis gereja ditusuk hingga luka parah oleh kelompok yang menentang kehadiran gereja tersebut. Sejak peristiwa itu gereja pun tidak dapat digunakan, dan mereka harus berpindah tempat. Demikian juga halnya dengan Gekindo Jatimulya, gereja ini juga harus memindahkan tempat ibadah mereka, ketempat yang cukup jauh dari lokasi gereja awal, ini berarti jemaat harus mengalami kesulitan menjangkau tempat ibadah itu. Nasib yang sama juga dialami oleh GKI Jatibening, tempat ibadah itu ditutup dan tidak bisa digunakan 
lagi.

Berdasarkan kejadian-kejadian tragis yang dialami gerejagereja di Bekasi atas kehadiran SKB yang kemudian direvisi menjadi PBM, dan keduanya mengharuskan adanya izin pemerintah daerah dan masyarakat atas sebuah rumah ibadah, wajar saja jika para pemimpin gereja di Bekasi pada umumnya berpendapat sama, yakni PBM yang mensyaratkan pendirian rumah ibadah berbeda dengan pendirian rumah tinggal telah mempersulit pendirian rumah ibadah. Pendirian rumah ibadah di Bekasi kerap lebih sulit dibandingkan pendirian sebuah tempat hiburan malam yang kehadirannya jelas-jelas bisa menimbulkan dampak negatif pada masyarakat setempat, apalagi dengan adanya penyimpangan pengoperasian hiburan malam, yang kerap menjadi tempat penjualan dan penggunaan narkoba.

Perizinan gereja yang dituangkan dalam PBM telah mengakibatkan beberapa gereja di Bekasi ditutup, seperti yang terjadi dengan HKBP, Gekindo, dan GPDI di Jati Mulya Bekasi, penutupan tersebut langsung dipimpin oleh camat setempat. Aturan keharusan adanya izin pemerintah telah melahirkan politisasi agama, di mana pejabat setempat memainkan agama untuk menarik simpati pendukungnya. Dan mempersulit atau menutup rumah ibadah yang berbeda dengan pendukungnya adalah jalan politisasi agama yang sangat berbahaya bagi keutuhan bangsa Indonesia. 


\section{PBM Berdampak Negatif dalam Hubungan Antaragama di Bekasi}

Apabila dalam SKB dua menteri perizinan bergantung pada kepala daerah, dan ini pun terbukti dimanfaatkan untuk kepentingan individu atau kelompok tertentu, maka syarat yang lebih detail tentang pendirian rumah ibadah justru menjadi lebih pelik. Pada daerah-daerah tertentu di Bekasi dijumpai, bahwa keharusan mendapatkan izin dari masyarakat setempat justru menimbulkan konflik baru dalam masyarakat. Individu atau kelompok masyarakat yang sebelumnya tak peduli dengan kehadiran rumah ibadah yang berbeda dengan agama yang mereka anut, kemudian secara tidak langsung merasa dipaksa untuk peduli dengan menyetujui kehadiran rumah ibadah agama yang berbeda. Permintaan persetujuan individu-individu yang berdomisili di sekitar rumah ibadah yang akan didirikan membuat penganut agama lain merasa dipaksa untuk menyetujui kehadiran rumah ibadah agama lain.

Keharusan mendapatkan izin masyarakat setempat untuk IMB pada beberapa gereja justru menjadi kontraproduktif, karena telah menimbulkan koflik baru dalam masyarakat antaragama. Apalagi, pada individu atau kelompok-kelompok masyarakat tertentu, memberikan izin pendirian rumah ibadah yang berbeda agama, sama saja dengan mengkhianati agama mereka, karena membiarkan agama-agama yang berbeda berkembang dan mengancam perkembangan agama yang mereka anut. Realitas ini bukan hanya diakui oleh pemimpinpemimpin gereja di Bekasi, tetapi juga tokoh-tokoh masyarakat di Bekasi, bahkan isu ini tersebar luas khususnya pada daerah- 
daerah di mana terjadi konflik terkait pendirian rumah ibadah. ${ }^{26}$

Hadirnya PBM telah membuat hubungan antaragama di Bekasi penuh dengan kecurigaan. Kebaikan gereja terhadap masyarakat sekitar berupa keterlibatan dalam memberikan bantuan sosial kepada masyarakat sekitar yang tidak mampu, kerap dicurigai sebagai tindakan manipulatif, yaitu usaha untuk membujuk masyarakat agar bersedia memberikan izin pendirian gereja. Padahal, kebaikan gereja tersebut sebenarnya tidak bisa ditafsirkan demikian, karena bantuan sosial gereja terhadap masyarakat adalah salah satu penunaian tugas mandat sosial gereja.

Kehadiran PBM menurut pemimpin-pemimpin gereja di Bekasi adalah "bukti kegagalan pemerintah untuk bersikap netral". Pemerintah jelas-jelas berpihak pada kelompokkelompok tertentu yang tidak senang dengan perkembangan agama lain. Kegagalan pemerintah untuk bersikap netral terlihat jelas dengan membiarkan terjadinya penutupan dan perusakan gereja oleh polisi-polisi informal, pemerintah tunduk pada polisi-polisi informal tersebut. Polisi-polisi informal itu umumnya bukan berasal dari masyarakat sekitar, tetapi berasal dari tempat yang jauh dari lokasi yang kerap menjadi sasaran amuk polisi-polisi informal itu." 27 Kegagalan pemerintah di Bekasi terlihat jelas dalam kasus HKBP Filadelfia Bekasi, yang dari segi jumlah telah memenuhi syarat dan

${ }^{26}$ Wawancara dengan pemimpin-pemimpin gereja di Bekasi.

27 Ibid. 
mendapatkan persetujuan masyarakat, serta diteguhkan keabsahannya oleh pengadilan. Namun hingga saat ini jemaat HKBP Filadelfia tidak mendapatkan haknya untuk mendapatkan izin IMB rumah ibadah. Bahkan ironisnya, pendeta jemaat HKBP Filadelfia yang adalah korban itu, sempat dituduh sebagai pelaku kekerasan. Dan pada sisi lain, pelaku kekerasan yang sebenarnya, tak pernah tersentuh aparat keamanan.

Birokrasi yang amat panjang dalam pendirian gereja, telah membuat gereja-gereja di Bekasi harus menyusuri jalan panjang dalam pendirian gereja. Birokrasi yang panjang tersebut juga kemudian melahirkan mafia-mafia dalam pengurusan gereja. Repotnya, mafia-mafia pengurusan izin gereja ini juga melibatkan pemerintah. Hal itu sebenarnya sudah dapat diprediksi, karena dalam PBM ada dua regulasi yang harus dipenuhi dalam pengurusan izin gereja, yakni regulasi pemerintah dan regulasi masyarakat. Mafia-mafia dalam pengurusan izin gereja ini bisa hadir dari pemerintah dengan birokrasinya, dan juga masyarakat. Birokrasi yang panjang ini mengakibatkan biaya pendirian gereja sangat besar. Dan itu juga yang menyebabkan pengurusan izin gereja memerlukan waktu yang amat panjang. Di Bekasi, pengurusan izin tercepat berlangsung selama dua tahun. Pendirian gereja yang sangat mahal itu mengakibatkan hanya gereja-gereja dengan jumlah jemaat yang besarlah yang dapat memenuhinya, sedang gerejagereja yang kecil hanya dapat menempati ruang ibadah sementara di ruko-ruko dan harus siap menjadi sasaran penutupan kelompok-kelompok tertentu, dan juga pemerintah 
daerah yang tidak memahami PBM dengan baik. Kondisi ini juga menimbulkan hubungan yang tidak baik dalam internal gereja, khususnya antara gereja berjumlah jemaat besar dan gereja dengan jemaat kecil. Apalagi umumnya gereja-gereja yang telah memiliki izin itu "enggan" meminjamkan gedung gereja mereka, meski sedang tidak digunakan.

Berdasarkan hasil penelitian di atas jelaslah bahwa menurut pendapat pemimpin-pemimpin gereja di Bekasi, PBM tidak produktif dan implementasinya berdampak buruk dalam kehidupan antaragama di Bekasi. PBM terbukti dimanfaatkan kelompok-kelompok diskriminatif untuk menutup rumahrumah ibadah. Padahal ada banyak rumah ibadah yang telah berdiri cukup lama, dan diterima baik oleh masyarakat, namun dengan memperalat peraturan yang bersifat diskriminatif itu, rumah-rumah ibadah itu pun mengalami gangguan. Beberapa di antaranya bahkan tutup dan pindah tenpat. Dari berbagai fakta itu, terbuktilah bahwa PBM 2006 memberikan legitimasi terhadap tindakan diskriminatif. PBM juga terbukti telah menghalangi hak komunitas agama untuk memiliki tempat beribadah.

\section{KESIMPULAN}

Berdasarkan Pancasila dan UUD 45, dokumen DUHAM 1948, Kovenan Internasional Hak-Hak Sipil dan Politik, dokumen Deklarasi untuk Mengeliminasi Segala Bentuk Praktik Intoleransi dan Diskriminasi Berdasarkan Agama dan Kepercayaan (Declaration on Elimination of All Forms Intolerance and Discrimination Based on Religion or Belief), Dokumen 
Deklarasi untuk Melindungi Hak-hak Individu Minoritas untuk Bidang Nasionalitas/Etnis, Agama, dan Bahasa (Declaration on the Rights of Persons Belonging to National or Ethnic, Religious and Linguistic Minorities), jelaslah bahwa PBM bersifat diskriminatif dan telah merampas hak masyarakat Bekasi untuk mendirikan rumah ibadah yang dijamin oleh undang-undang di atasnya, dalam hal ini UUD 1945. Kehadiran PBM juga berdampak buruk dalam kehidupan internal agama, dan hubungan antaragama di Bekasi. Berdasarkan pendapat pemimpinpemimpin gereja di Bekasi, PBM harus dicabut, karena syaratsyarat pendirian gereja berdasarkan PBM jelas-jelas telah membatasi hak umat beragama di Bekasi untuk memiliki tempat ibadah. 